STUDIA PRAWNO-EKONOMICZNE, T. CVI, 2018

PL ISSN 0081-6841; $\quad$ e-ISSN 2450-8179 $\quad$ s. 143-164

https://doi.org/10.26485/SPE/2018/106/9

\title{
Tomasz TULEJSKI*
}

\section{JOHN LILBURNE - CZŁOWIEK, KTÓRY ZA BARDZO UWIERZYŁ W WOLNOŚĆ}

\begin{abstract}
(Streszczenie)
Lewellerzy byli ruchem politycznym działającym podczas angielskiej wojny domowej, który opowiadał się za radykalnymi reformami politycznymi, ponieważ ich Agreement of the People zawierały prawdopodobnie pierwsze nowożytne idee demokratyczne formalnie opracowane i zaadoptowane przez ruch polityczny. Jednym z liderów lewellerów i wpływowym agitatorem politycznym był John Lilburne, oficer Armii Nowego Wzoru, znany również jako Freeborn John. W niniejszym artykule autor próbuje z jego mów, listów i manifestów politycznych zrekonstruować spójną doktrynę Lilburne'a. Dowodzi, że myśl Freeborn Johna jest zakorzeniona w baptystycznej teologii, ponieważ jego argument społeczny i polityczny jest sekularyzacją baptystycznej koncepcji genezy kościoła. Z faktu, że władza kongregacji wywodziła się z równości i odpowiedzialności wiernych pod władzą Chrystusa, że w Jezusie Chrystusie wszyscy ludzie są równi i każdy jest wolny w relacji z Bogiem, i wyznaje swą wiarę dobrowolnie, Lilburne wywodzi uniwersale i naturalne uprawnienia, konwencjonalne pochodzenie społeczeństwa, rozszerzenie praw wyborczych, powszechną równość wobec prawa i tolerancję religijną.
\end{abstract}

Słowa kluczowe: Lilburne; lewellerzy; angielska wojna domowa

\section{Wstęp}

Gdy spadła głowa Karola I i wkrótce formalnie zniesiono monarchię, przed królobójcami stanęło zadanie stworzenia nowego ładu instytucjonalnego, który zastąpić miał znienawidzoną tyranię. Lecz jak pokazują rewolucje, ponieważ o wiele łatwiej jest niszczyć niż budować, w obozie zwycięzców dały o sobie znać fundamentalne różnice zdań. To, nad czym trzeba było przejść do porządku dziennego, gdy żył tyran, teraz wybuchło ze zdwojoną siłą, sprawiając,

* Dr hab., prof. UŁ, Uniwersytet Łódzki, Wydział Prawa i Administracji, Katedra Doktryn Polityczno-Prawnych; e-mail: ttulejski@o2.pl 
że Anglia pogrążyła się praktycznie w anarchii. Z jednej strony bowiem formalnie rządził prezbiteriański Kadtub, realizujący marzenia purytańskich kaznodziejów z czasów Elżbiety I. Zniesiono więc episkopat i Book of Common Prayer, wprowadzając nową zdecentralizowaną organizację kościoła kontrolowanego przez suwerenny w swym mniemaniu Parlament. Choć zostali w nim najwierniejsi z wiernych, to dla nich cele rewolucji zostały osiągnięte i nie byli chętni na zbyt daleko idące eksperymenty, a nowy gmach instytucjonalny, jakkolwiek miałby wyglądać (nie wykluczano także powrotu monarchii), miał $\mathrm{w}$ istocie petryfikować dotychczasową strukturę społeczeństwa. W opozycji do Parlamentu stali independenci, o wiele bardziej radykalni w swych planach politycznych i ekonomicznych, którzy choć o wiele mniej liczni, mieli w swych szeregach utalentowanych przywódców, to do nich należeli bowiem Cromwell, Goodwin, Vane i Milton. Przeciwni byli monopolowi kościoła prezbiteriańskiego, domagając się tolerancji religijnej dla sekciarzy (a Goodwin nawet dla katolików $\left.{ }^{1}\right)$. To oni w końcu stali za egzekucją króla i wprowadzeniem republiki i to do nich w ich przekonaniu miała należeć decyzja, w którą stronę zmierzać będzie Anglia. To jednak, co dla prezbiterian było końcem, dla independentów jego początkiem, to dla wielu innych zalewie końcem początku. Istotna bowiem część Armii Nowego Wzoru, rekrutująca się w przeważającej mierze z drobnych kupców, rzemieślników i farmerów, zradykalizowała się w roku 1647 pod wpływem agitacji prowadzonej przez bezkompromisowych przeciwników tak parlamentu, jak i armijnych grandów. Dostrzegali oni bowiem w zwycięstwie szansę gruntownej przebudowy państwa angielskiego w bardziej egalitarnym duchu. Ich radykalne przekonania, jak większości uczestników ówczesnej debaty, miały głęboko religijne fundamenty, bardzo wielu z nich, a przynajmniej przywódcy z szeregów armii było kwakrami i baptystami lub z sektami tymi sympatyzowało ${ }^{2}$. Szczególnie duże wpływy ta ostatnia sekta posiadała w korpusie oficerskim ${ }^{3}$. Baptyści byli i pozostali separatystami dystansującymi się od kościoła anglikańskiego tak w formie episkopalnej, jak i prezbiteriańskiej. Choć ich teologiczne powinowactwo z purytanami jest $\mathrm{w}$ wielu kwestiach oczywiste, to nie zamierzali oczyścić kościoła i doprowadzić do końca reformacji w kalwińskim duchu, sprzeciwiali się bowiem samej idei kościoła państwowego.

J. Lecler, Historia tolerancji w wieku reformacji, przekł. L. Kühn, H. Kühn, t. II, Pax, Warszawa 1964 , s. 420-421.

2 D.M. Wolfe, Introduction, w: D.M. Wolfe (ed.), Leveller Manifestoes of Puritan Revolution, Thomas Nelson and Sons, New York, London, Edinburgh, Toronto, Melbourne 1944, s. 3; L.F. Brown, The Political Activities of the Baptists and Fifth Monarchy Men In England During the Interregnum, Oxford University Press, London 1912, s. 11-12.

3 A.C. Underwood, A History of the English Baptists, Kingsgate Press, London 1947, s. 74-77. 
Jednym z najważniejszych założeń baptystów była koncepcja indywidualnej wolności duszy, która oznacza jednostkowe uprawnienie zbliżenia się do Boga i jego osobistej interpretacji. Każda dusza bowiem ma wystarczające kompetencje, by wejść w indywidualne relacje z Bogiem, mając do tego niezbywalne uprawnienie. Żaden inny człowiek czy też grupa nie może przy tym zmusić jednostki do obrania tej czy innej drogi poznania Stwórcy niż ta wybrana przez jednostkę. Każde takie działanie jest zatem w oczach Boga złem, ponieważ wszyscy ludzie są stworzeni jako równi i wyposażeni w podobne zdolności, obowiązki i przywileje pochodzące bezpośrednio od Niego. Błędne są zatem poglądy, które wynoszą jednych ludzi ponad innych, bowiem w oczach Boga jest tylko jednostka, z którą wchodzi w relacje, nie ma kast czy klas, nie ma arystokracji i duchowieństwa. Wszyscy stoją naprzeciw Niego sami jako wolne i równe podmioty. Choć między ludźmi istnieją różnice zdolności, to nie mają one żadnego wpływu na uprawnienie indywidualnego dostępu do Boga. Równocześnie u każdego chrześcijanina istnieje potrzeba łączenia się z tymi, którzy wierzą tak samo jak on, ponieważ wspólnota jest ważnym i koniecznym wkładem do jego duchowego komfortu i rozwoju. Lecz wstąpienie do niej jest świadomym aktem woli wierzącego, a chrzest niemowląt jest pogwałceniem tej zasady, odbierając człowiekowi prawo indywidualnego wyboru ${ }^{4}$. To radykalnie woluntarystyczne i indywidualistyczne podejście do wiary, przełożone na język polityki oznaczało zupełnie nowe, również indywidualistyczne podejście do genezy społeczeństwa i ostatecznie to w nim upatrywanie rzeczywistego podmiotu suwerenności ${ }^{5}$, w kwestii religii natomiast powszechną tolerancję

I.

Myśl lewellerów ma więc głębokie religijne korzenie, jako wierzący chrześcijanie nie mogą ignorować roli Boga, widząc go jako źródło wszelkiej prawdy i prawa naturalnego. Jest ono bowiem, jak napisał bohater niniejszej analizy,

4 Ch. Hill, The World Turned Upside Down. Radical Ideas During the English Revolution, Penguin Books, London 1991, s. 99.

5 A.L. Morton, World of the Ranters. Religious Radicalism in the English Revolution, Lawrence \& Wishart, London 1970, s. 14.

6 D. Wootton, Leveller democracy and the Puritan Revolution, w: J.H. Burns, M. Goldie (ed.), The Cambridge History of Political Thought 1450-1700, Cambridge University Press 1994, s. 442; W. Haller, Commentary, w: W. Haller (ed.), Tracts on Liberty in the Puritan Revolution 1638-1647, vol. I, Columbia University Press, New York 1934, s. 53-63. 
„naturalnie zapisane palcem Boga w naszych sercach"”, a jego zasadą naturalna wolność wszystkich ludzi. Podczas swego procesu w 1653 r. po raz kolejny stwierdził, że jedynym królem jest Jezus, a „najwierniejsi słudzy Chrystusa w każdym kraju, w którym żyją" są najgorliwszymi obrońcami prawa i wolności ${ }^{8}$. Jako, że przywódcy lewellerów nie byli ludźmi o gruntownym wykształceniu ${ }^{9}$, nie znali łaciny, greki czy hebrajskiego, nie byli biegli w klasycznej filozofii, zatem Pismo Święte, współczesne im traktaty wydane po angielsku, Intitutions Coke’a i ich własne intuicje i doświadczenia były dla nich jedynym przewodnikiem w działaniach politycznych. Nie stworzyli zatem koherentnego systemu, a ich myśl jest raczej platformą polityczną domagającą się radykalnych politycznych przeobrażeń w nowej rzeczywistości, jaka nastała w trakcie i po wojnie domowej. Dlatego przybiera ona postać apeli, odezw, petycji ${ }^{10}$ i propozycji konkretnych rozwiązań znajdujących ostatecznie wyraz w pierwszym projekcie konstytucji pisanej ${ }^{11}$, z których niełatwo jest wydestylować filozoficzną bazę.

Szczególnie jednak jeden z oficerów sprawiał problemy Parlamentowi i był przyczyną bólu głowy Cromwella. John Lilburne, bo o nim tu mowa, z którym związana jest cała historia i legenda ruchu, już za czasów Karola dał się poznać jako nieprzejednany radykał i przeciwnik kościoła episkopalnego za co przez Sąd Izby Gwiaździstej skazany został na karę chłosty i wię$z_{i e n i e}{ }^{12}$. Już wtedy głosił też właściwy dla baptystów pogląd o dobrowolnym i konwencjonalnym charakterze kościoła oraz wspólnoty politycznej ${ }^{13}$. Teraz zaś, jako weteran wojny domowej w stopniu podpułkownika, stanął na czele stronnictwa pogardliwie nazywanego w Putney przez Iretona lewellerami ${ }^{14}$

7 J. Lilburne, A copy of a Letter from the Agents of the Aforesaid Five Regiments of Horse, unto His Excellency Sir Thomas Fairfax, w: W. Haller, G. Davies (ed.), The Leveller Tracts, 1647-1653, Peter Smith, Gloucester 1964, s. 85.

8 J. Lilburne, The Just Defense of John Lilburne, Against Such as charge him with Turbulency of Spirit, w: W. Haller (ed.), Tracts on Liberty..., s. 452.

9 J.P. Sommerville, Absolutism and revolution in the seventeenth century, w: J.H. Burns, M. Goldie (ed.), The Cambridge History of Political Thought, 1450-1700, Cambridge University Press, Cambridge 1991, s. 413.

10 Z których wiele wydanych zostało anonimowo bądź ich autorstwo budzi do dziś spory.

11 F.D. Wormuth, The Origins of Modern Constitutionalism, Harper, New York 1949, s. 44; J.P. Sommerville, Absolutism and revolution in the seventeenth century..., s. 412.

12 P. Gregg, Free-Born John. The Biography of John Lilburne, Phoenix Press, London 2000, s. 52-63.

13 P. Zagorin, A History of Political Thought in the English Revolution, Routledge \& Kegan Paul, London 1965, s. 9.

14 A. Sharp, Introduction, w: A. Sharp (ed.), The English Levellers, Cambridge University Press, Cambridge, New York, Melbourne 1998, s. xxi-xxii. 
i domagającego się wprowadzenia prodemokratycznych rozwiązań ustrojowych nie do zaakceptowania przez twardych republikanów ${ }^{15}$. Pragnęli bowiem uznania suwerenności ludu, równej dystrybucji prawa reprezentacji, regularnych wyborów, swobody religijnej i uznania naturalnych uprawnień. Był to więc sprzeciw nie tylko wobec zasad, na których ufundowana była monarchia, lecz także wobec ograniczonej dystrybucji suwerenności głoszonej przez Cromwella i republikańską elitę.

Fundamentem filozofii politycznej Lilburne'a i lewellerów było bowiem przekonanie o posiadaniu przez każdego człowieka takich samych, przyrodzonych uprawnień (birthrights). To polityczne credo wyłożył Lilburne w roku 1645 podczas przesłuchania przed Parlamentem: ,Jestem wolnym człowiekiem, zaprawdę, wolno urodzonym (free-born) mieszkańcem Anglii, byłem na polu bitwy ze swym mieczem, by zaryzykować swe życie i moją krew przeciwko tyranom, by zachować mą wolność i nie wiem, bym kiedykolwiek popełnił w mym życiu czyn, który pozbawiłby mnie mojej wolności i zniweczył bycie wolnym człowiekiem, wierzę, że mam prawdziwe uprawnienie do wszystkich tych przywilejów, które należne są wolnemu człowiekowi, takich samych, jakie ma największy człowiek w Anglii" "16. Mówiąc o wolnościach i uprawnieniach używa przy tym terminu, którym wcześniej w Anglii się nie posługiwano, zamiast o „free-born subject" mówi bowiem o „free-born Englishman" ${ }^{17}$. Dla przywódcy lewellerów liczy się zatem przede wszystkim to, że Bóg jest twórcą człowieka i jako twórca miłosierny i dobry obdarzył swoje stworzenie wolnością i niezbywalnymi atrybutami, które pochodzą wprost z Jego woli ${ }^{18}$. Uprawnienia te, co jest nowością w XVII w., nie są zatem związane z państwem czy konkretnym ustrojem, całkowicie abstrahują od idei wspólnoty, która wtedy najczęściej była podmiotem uprawnień, lecz mają charakter indywidualny, pierwotny i przyrodzony. Wynikają z faktu stworzenia człowieka przez Boga na jego obraz i podobieństwo, mogą też w oczywisty sposób zostać odkryte przez rozum ${ }^{19}$.

15 S.D. Glover, The Putney Debates: Popular versus Élitist Republicanism, Past \& Present, 1999 (Aug.)/164, s. 47-80.

16 Cyt. za: W. Godwin, History of The Commonwealth of England. From its Commencement, to The Restoration of Charles The Second, vol. II, Henry Colburn, London 1826, s. 20.

17 R. Foxley, John Lilburne and the Citizenship of "Free-born Englishmen", The Historical Journal 2004/47/4, s. 851.

18 J. Lilburne, The freeman's freedom vindicated. Postscript, containing a general proposition, w: A. Sharp, The English Levellers..., s. 31.

19 J. Lilburne, London's Liberty in Chains discovered, A Postscript written by Lieutenant Colonell Iohn Lilburn, Prisoner in the Tower of London, nn, London 1646, s. 14. 
II.

Jednostka ludzka i jej uprawnienia tworzą podstawę całej struktury społecznej, są nieprzenaszalne, ponieważ nie można się ich zgodnie z rozumem wyzbyć, nienaruszalne, ponieważ nie można uzasadnić pozbawienia ich nas przez nikogo, jednostki czy państwo. Uprawnienia naturalne konstytuują zatem naturalną i przyrodzoną wolność jednostki, lecz wolność Lilburne'a to nie samowola i możność czynienia tego, co się chce, nie może być bowiem użyta, by szkodzić innym i odbierać im wolność. Absolutnie wolny jest tylko Bóg, wolność człowieka osadzona jest natomiast w chrześcijańskiej moralności, a czynienie zła innym upodabnia do diabła, który za swą pychę strącony został do otchłani ${ }^{20}$. Człowiek winien być całkowicie podporządkowany woli Boga, która jest ,jarzmem poddaństwa [...], które jest na szyjach wszystkich ludzi”21 i która czyni go częścią wielkiej ludzkiej wspólnoty. Narzuca on przez to swym dzieciom obowiązki moralne wobec bliźnich, żądając od nich troski o dobro innych. Miłość własna, samolubstwo i egoizm bowiem, jak napisał Lilburne, jest niczym ,puchar złota w rękach ladacznicy”22. Ponieważ poddaństwo jest sprzeczne z naturą i wolą Boga, zatem chrześcijanin winien w życiu doczesnym podjąć wszelkie wysiłki, by spełnić Jego wolę i uczynić siebie i bliźnich wolnymi. Wierzący to nie ten, który chwali Boga poprzez rytuały, posty i święta, lecz ten, kto przez swe działanie pragnie uczynić „,uciskanych wolnymi”"23. Dlatego jest ,zasadą moralną, że chwała wielkiego i suwerennego Stwórcy oraz dobro wspólne Królestwa lub Miasta powinny być preferowane przed partykularną wolnością i dobrobytem jednostki”24. Znajdziemy zatem u Lilburne'a istotny republikański i chrześcijański komponent, jak niemal u wszystkich liczących się wówczas aktorów Wielkiej Rebelii. „Odkąd - czytamy - żaden człowiek nie urodził się tylko dla siebie, lecz zobowiązany jest przez prawo natury (które wiąże wszystkich), chrześcijaństwo (które czyni nas chrześcijanami) i społeczeństwo i rząd, by podejmować wysiłki dla postępu powszechnego

20 J. Lilburne, London's Liberty in Chains discovered, A Postscript..., s. 42.

21 J. Lilburne, A Declaration to the Free-Born People of England, Concerning the Government of the Commonwealth, George Horton, London 1654, s. 6.

22 J. Lilburne, An Answer to Nine Arguments. Written by T.B., nn, London 1645, s. 2.

23 J. Lilburne, England's Weeping Spectacle: Or, The Sad Condition of Lieutenant Colonell John Lilburne, nn, London 1648, s. 13.

24 J. Lilburne, The Prisoners Plea for a Habeas Corpus: Or an Epistle Writ by L.C. Joh. Lilburne Prerogative Prisoner in the Tower of London the 4. of Aprill, to the Honourable Mr. W. Lenthall Speaker of the House of Commons, nn, London 1648, s. 10. 
szczęścia, troszcząc się o innych, tak jak o siebie"25. Nakazem dobrego obywatela jest zatem publiczna cnota, wierność zasadom i nieustępliwość w obronie wolności własnej i innych ${ }^{26}$. Lecz wolność rozumie Lilburne przede wszystkim jako wolność od zniewolenia, choć łączy się ona z aktywnym działaniem publicznym jako warunkiem wstępnym i koniecznym do obrony przed dominacją oraz obowiązkami moralnymi wobec członków wspólnoty. Człowiek jest wolny tylko jako część wolnej wspólnoty niepodlegającej władzy zewnętrznego wobec niej autorytetu oraz posiadając uprawnienia, których nawet wspólnocie nie wolno pogwałcić.

III.

Ten prawnonaturalny argument Lilburne'a wzmocniony jest komplementarną argumentacją, odwołującą się do angielskiej tradycji konstytucyjnej i Magna Charta. Jej jądrem było przeciwstawienie czasów anglosaskich reprezentujących swoisty złoty wiek temu, co nastąpiło po normandzkim podboju. Przed najazdem Wilhelma Anglicy byli według nich wolnym narodem, a władza królów anglosaskich oparta była na powszechnej i dobrowolnej zgodzie. Kres temu położył najazd z roku 1066, który zamienił wolnych obywateli w niewolników, uczynił też niewolną całą wspólnotę polityczną ${ }^{27}$. Z tego okresu pochodzą wszelkie przywileje szlachty i królewska prerogatywa, których źródłem jest przemoc i uzurpacja. Aktualne prawo wywodziło się z tyranii Wilhelma i podobnie jak jego rządy nie posiadało legitymacji. Utrzymywało i wzmacniało jedynie stan poddaństwa i zniewolenia angielskiego ludu przez królów będących następcami Zdobywcy i szlachtę. Każdoczesny władca był następcą Zdobywcy, a lordowie byli dla Lilburne'a następcami jego rycerzy panującymi nad ludem Anglii za pomocą miecza. Parlamenty zaś to wspólnicy królów w zniewoleniu wolnych Anglików ${ }^{28}$. Ich spojrzenie na historię było zatem dalekie od tego, jakie prezentowali bardziej konserwatywni adwersarze, widzące ciągłość pomiędzy przeszłością a teraźniejszością, która w ten sposób

25 J. Lilburne, W. Walwyn, Th. Price, R. Overton, A Manifestation from Lieutenant Col. John Lilburn et al., w: W. Haller, G. Davies, The Leveller Tracts, 1647-1653, s. 277.

26 J. Lilburne, The Just Defense..., s. 455.

27 Q. Skinner, Visions of Politics, vol. III: Hobbes and Civil Science, Cambridge University Press, Cambridge, New York, Melbourne, Madrid, Cape Town 2002, s. 248.

28 G. Burges, Repacifying the polity: the responses of Hobbes and Harrington to the 'crisis of the common law', w: I. Gentles, J. Morrill, B. Worden (ed.), Soldiers, writers and statesmen of the English Revolution, Cambridge University Press, Cambridge 1998, s. 205. 
znajdowała usprawiedliwienie ${ }^{29}$. Tymczasem Lilburne i lewellerzy odrzucali niemal wszystko, co stało się pomiędzy rokiem 1066 a wojną domową, stąd też wynikała fundamentalna krytyka istniejącego społeczeństwa i prawa. Podbój normandzki był bowiem przerwaniem ciągłości angielskiego prawa i ewolucji angielskiej konstytucji, dlatego odwoływali się nie do historii, lecz teorii naturalnych uprawnień i przednormańskiego mitu. Prawo angielskie, jak wskazuje Skinner, było zatem dla nich jarzmem, poza nielicznymi elementami, które przetrwały $z$ anglosaskiego raju ${ }^{30}$. Całkowicie ignorując jego historyczny kontekst, uczynili z niego swego rodzaju fetysz, ponieważ, jak twierdzili, prawo z czasów królów anglosaskich czyniło Anglików wolnymi ludźmi, dając im uprawnienia i przywileje jedynie na mocy tego, że są Anglikami. Trzeba było zatem przywrócić te zapomniane i podeptane prawa Anglosasów ${ }^{31}$. Miało to też dla Lilburne'a istotny kontekst teologiczny, ponieważ tyrania jest ustrojem sprzecznym z wolą Boga. Zatem jeśli udałoby się przywrócić stare prawa i oddać Stwórcy miejsce jedynego wszechwładnego władcy, wtedy, miał nadzieję, obdarzyłby Anglików łaską i uczynił nowym narodem wybranym, otoczonym jego szczególną opieką ${ }^{32}$. Ostatnie 600 lat to więc próba odzyskania tego anglosaskiego dziedzictwa, starych wolności z czasów Edwarda Wyznawcy i zrzucenia jarzma tyrani, znaczona takimi osiągnięciami jak Magna Charta i Petition of Rights. To w nich oraz niektórych instytucjach common law przetrwały wolności Anglików, dlatego Lilburne w czasie swego procesu o zdradę w roku 1649 pojawił się przed sądem uzbrojony w Institutes Coke'a, a odwołując się do nich, pisze o Wielkiej Karcie: „Lecz te wolności i przywileje nie pochodziły z łaski czy daru, lecz z uprawnienia i dziedzictwa. Ten doświadczony i uczciwy prawnik mówi nam, że nie było to niczym więcej (w przeważającej mierze) jak deklaracją najważniejszych podstaw fundamentalnych praw Anglii”33.

29 J.G.A. Pocock, The Ancient Constitution and the Feudal Law. A Study of English Historical Thought in the Seventeenth Century. A Reissue with a Retrospect, Cambridge University Press, Cambridge, London, New York, New Rochelle, Melbourne, Sidney 1987, s. 126.

30 Q. Skinner, History and ideology in the Puritan Revolution, Historical Journal 1965/VIII/2, s. $153-154$.

31 G. Burges, The Politics of the Ancient Constitution. An Introduction to English Political Thought, 1603-1642, Palgrave Macmillan, Basingstoke, London 1992, s. 90.

32 J. Lilburne, Strength Out of Weaknesse: or, the Final Plea of J. Lilburne, nn, London 1649, s. 20.

33 J. Lilburne, Liberty Vindicated against Slavery, Shewing, that Imprisonment for Debt, Refusing to Answer Interrogatories, Long Imprisonment, Though for Just Causes, nn, London 1646, s. 2. 
Ostatecznie więc u Lilburne'a uprawnienia mają podwójną naturę, są po pierwsze naturalne, wywiedzione z prawa naturalnego, które tożsame było $\mathrm{z}$ angielską konstytucją okresu przednormańskiego. To w niej miała miejsce doskonała zgodność pomiędzy uprawnieniami naturalnymi i uprawnieniami prawnymi, prawem Bożym, prawem natury i prawem ludzkim. Jesteśmy jednak wolni nie dlatego, że stanowi tak prawo pozytywne, lecz dlatego, że wolni jesteśmy z samej natury, a swobody nasze wyprowadzane są z naturalnych i przyrodzonych uprawnień, zawierała też tylko część twego, co uważali za przyrodzone wolności Anglików ${ }^{34}$. Wyprzedzają one zatem zwyczaj i Magna Charta, które są oczywiście ich prawną konkretyzacją i instrumentem ochrony w warunkach prawa angielskiego, lecz nie ich źródłem. Uprawnienia są zatem równocześnie naturalne, starożytne, fundamentalne, powszechne, indywidualne, przyrodzone. Starożytne prawa Anglii tworzące zadawnioną konstytucję są zatem godne pochwały, lecz jak wskazuje Lilburne, tylko wtedy, gdy ,zgodne są ze słowem Bożym, prawem natury i głosem rozumu" ${ }^{35}$. Akceptuje więc $\mathrm{z}$ radością stare prawa i zwyczaje praktykowane w Anglii, jednak pod warunkiem ich zgodności $\mathrm{z}$ prawem wiecznym i prawem naturalnym ${ }^{36}$. Lilburne w swojej argumentacji korzysta więc z Coke'a bardzo wybiórczo, ponieważ ten nie posługuje się językiem prawa naturalnego i naturalnych uprawnień, lecz niknącego $\mathrm{w}$ pomroce dziejów starożytnego zwyczaju ${ }^{37}$. Starożytna konstytucja, tak jak ją widzieli parlamentarni prawnicy, nie ma zatem dla Lilburne'a automatycznej mocy wiążącej, nie posiada wrodzonej racjonalności, lecz tylko w zakresie, z jakim zgadza się z wyższym porządkiem normatywnym ${ }^{38}$. Jest tak, ponieważ antynormanizm był jednak najważniejszym elementem refleksji Lilburne'a nad prawem ${ }^{39}$. Nie wierzył bowiem, że odwieczność prawa wystarczy, by legitymizować jego treść i uznać racjonalność, a pisząc o prawach, stwierdził, że ich źródłem jest

34 M. Dzelzainis, Milton, the Levellers, and the Council of State, w: P. Kewes (ed.), The Uses of History in Early Modern England, University of California Press, San Marino 2006, s. 276.

35 J. Lilburne, London's Liberty in Chains discovered, A Postscript..., s. 41.

36 Idem; patrz: Th.C. Pease, The Leveller Movement. A Study in the History and Political Theory of the English Great Civil War, Oxford University Press, Washington, London 1916, s. $138-139$.

37 D.A. Orr, Law, liberty, and the English Civil War: John Lilburne's prison experience, the Levellers and freedom, w: M.J. Braddick, D.L. Smith, The Experience of Revolution in Stuart Britain and Ireland, Cambridge University Press, Cambridge, New York, Melbourne, Cape Town, Singapore, Sao Paulo, Delhi, Tokyo, Mexico City, s. 159-160.

38 J. Lilburne, Strength Out of Weaknesse..., s. 14.

39 A. Sharp, John Lilburne's Discourse of Law, Political Science 1988/40, s. 31. 


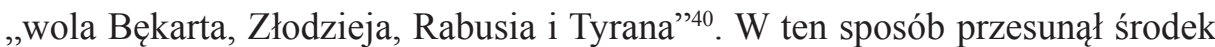
ciężkości z uprawnień historycznych na uprawnienia naturalne ${ }^{41}$.

Uprawnienia naturalne posiadamy niezależnie od społecznego kontekstu, w którym funkcjonujemy, posiadamy je w stanie naturalnym, prawa obywatelskie zaś jako członkowie społeczeństwa obywatelskiego. Są one jednak dwiema stronami tej samej monety, funkcjonują razem, mając ontologicznie charakter pierwotny wobec społecznych asocjacji. Zatem relacje pomiędzy jednostkami mają charakter egalitarny i dobrowolny, cała władza i jurysdykcja rozdzielone są równo, nikt nie ma jej więcej, nikt też z natury nie może sprawować władzy nad innymi. „Nikt jej nie ma - pisze Lilburne w The freeman's freedom vindicated - ani nie powinien wykonywać jak tylko przez ustanowienie lub donację, to znaczy za wspólną zgodą (agreement) lub pozwoleniem (consent) - udzieloną, wyprowadzoną lub przyjętą przez wspólną zgodę lub pozwolenie - dla korzyści i dobrobytu wszystkich, lecz nie dla szkody, bólu czy krzywdy kogokolwiek" ${ }^{\prime 2}$. Nikt nie może czynić z innego człowieka niewolnika, ponieważ Bóg w swoim rozumie stworzył świat, w którym „nie będzie tyranii jednego człowieka nad innym"43. Stworzenie na obraz i podobieństwo jest więc immanentnie połączone $\mathrm{z}$ równością i wolną wolą w poddaniu się władzy. Bezprawna dominacja jednych nad drugimi jest dla Lilburne'a ,przeciwna naturze i chwale obrazu Boga, na podobieństwo którego stworzył człowieka, jest hańbą dla niego samego i jego Twórcy i jedynego Pana i nie może być sprawiedliwa"44. W oczach Boga wszyscy są równi i prawdziwi chrześcijanie przyjąć powinni tę fundamentalną prawdę. Pierwsi z nich nie znali bowiem żadnej władzy, żadnego zwierzchnika, prócz tych ustanowionych za pośrednictwem ich powszechnej zgody i wyboru ${ }^{45}$. Dlatego jest ,nienaturalne, nieracjonalne i grzeszne" rozstanie się z władzą, jaką mamy nad samym sobą, jeśli władza ta ma być użyta do zniszczenia nas. Podobnie „nienaturalne, nieracjonalne, grzeszne, podłe, niesprawiedliwe, diabelskie i tyrańskie, niezależnie przez kogo - władcę duchownego czy świeckiego, księdza czy laika - przywłaszczenie sobie

40 J. Lilburne, Regall Tyrannie Discovered, Or, A Discourse Shewing that All Lawfull... Instituted Power by God Amongst Men, is by Common Agreement and Mutual Consent..., nn, London 1647, s. 9.

${ }^{41}$ K.V. Thomas, The Levellers and the franchise, w: G.E. Aylmer (ed.), The Interregnum. The Quest for Settlement, Archon Books, Hamden 1972, s. 64.

${ }^{42}$ J. Lilburne, The freeman's freedom vindicated. Postscript, containing a general proposition..., s. 31.

43 J. Lilburne, Regall Tyrannie Discovered..., s. 59.

44 Ibidem, s. 11.

45 J.P. Sommerville, Absolutism and revolution in the seventeenth century..., s. 427. 
i przejęcie władzy, autorytetu i jurysdykcji, by rządzić, lub panować nad jakimś rodzajem ludzi na tym świecie bez ich wolnej zgody" ${ }^{46}$. Z naturalnych uprawnień i przyrodzonej równości musi wynikać zatem dobrowolny charakter podległości i politycznego zobowiązania, a rządy wyprowadzane są od pozwolenia każdego obywatela. Wyrażone jest ono w formie umowy społecznej, która u Lilburne'a ma jednak nowatorski charakter.

\section{IV.}

Lilburne nie może zignorować faktu, że natura ludzka od czasów grzechu pierworodnego jest skażona, stąd państwo w jakiejś formie jest konieczne, by zniwelować tego konsekwencje, chroniąc życie, wolność i własność. Jego brak spowoduje pogrążenie się społeczeństwa w stanie dzikości i wzajemnych waśni, a „każdy człowiek stanie się prawem dla siebie [...] żądza stanie się prawem, zazdrość stanie się prawem, chciwość i ambicja staną się prawem" ${ }^{\text {"47 }}$. Analizując konsekwencje upadku państwa, Lilburn pisał, że „nie byłoby rozumu, lecz powszechne podrzynanie gardeł i wszystko wróciłoby do pierwotnego Chaosu, gdzie sędzią byłby najdłuższy miecz, a wszyscy zostaliby wkrótce zniszczeni w tym powszechnym rozkładzie i tumulcie"48. Ludzie żyjący w stanie natury, pozbawieni władzy są ,bardziej brutalni, krwawi i barbarzyńscy, niż najbrutalniejsze i najbardziej bezlitosne dzikie zwierzęta"49.

Obserwując rzeczywistość wojny domowej i tego, co stało się później, dochodzi do wniosku, że doszło przez to w istocie do przywrócenia w Anglii stanu natury ${ }^{50}$, ponieważ nie dokonuje rozróżnienia pomiędzy społeczeństwem i państwem, uważając je w istocie za to samo. Tę diagnozę potwierdzały jego osobiste doświadczenia: niepowodzenia w dochodzeniu sprawiedliwości, represje, które go spotkały, samowola Parlamentu wskazywały bowiem, że w Anglii prawa przestały działać, a rządzi jedynie siła. Anglia na powrót stała się bowiem taka, jaką stworzył ją Bóg, a Parlament stracił wszelkie swe uprawnienia. Stało się tak, ponieważ sam złamał pierwszorzędne prawa, wielokrotnie potwierdzane

${ }^{46}$ J. Lilburne, The freeman's freedom vindicated. Postscript..., s. 31.

47 J. Lilburne, The Grand Plea of Lieut. Col. John Lilburne: prerogative prisoner in the Tower of London, nn, London 1647, s. 5.

48 J. Lilburne, An Impeachment of High Treason against Oliver Cromwel, nn, London 1649, s. 14.

49 J. Lilburne, The Upright Mans Vindication or An Epistele writ by John Lilburne Gent. Prisonet in Newgate, August 1653, nn, London 1653, s. 15.

50 R. Foxley, The Levellers. Radical Political Thought in the English Revolution..., s. 75. 
jego własnymi aktami, wynikające z natury, rozumu i sprawiedliwości, nakazujące mu ochronę i zapewnienie bezpieczeństwa wolnym Anglikom. Przestał być ciałem przedstawicielskim, a stał się jedynie grupą depczącą prawo i sprawującą nieograniczoną i niczym niepowstrzymaną władzą ${ }^{51}$.

Zaistniał zatem moment konstytucyjny, który jest dla Lilburne'a doskonałą okazją ustanowienia ustroju sprawiedliwego, respektującego naturalne uprawnienia. Dlatego „po długim i uciążliwym prowadzeniu nienaturalnie okrutnej wojny domowej spowodowanej przez podziały i różnice pomiędzy nami oraz z powodu dolegliwości wynikających z niepewności naszych rządów i sprawowania nieograniczonej i arbitralnej władzy celem jest zniszczyć wszelką arbitralną władzę i ustanowić granice limitu zarówno dla najwyższej, jak i wszelkiej podporządkowanej jej władzy oraz usunąć wszystkie znane uchybienia" ${ }^{52}$. Mając równość władzy i jurysdykcji, mogą dokonać tego jedynie w drodze powszechnej zgody. Umowa ta nie jest czysto hipotetycznym założeniem będącym podstawą porządku politycznego, nie jest fikcją metodologiczną, nie jest także aktem historycznym dokonanym jakoby w zamierzchłej przeszłości, lecz dosłownym źródłem ładu społecznego i politycznego, dokonanym tu i teraz, by „zdjąć wszelkie jarzmo, uwolnić od wszelkiego brzemienia, wyzwolić zniewolonego i uczynić uciskanego wolnym" ${ }^{53}$. Przywraca ona istnienie państwa i społeczeństwa wrzuconych w stan natury przez tyranię. Agreement of the People nie jest więc projektem konstytucji opartym na abstrakcyjnych zasadach, lecz esencją wolnościowego ustroju Anglii sprzed inwazji zawartą w jednym jasnym i zrozumiałym akcie ${ }^{54}$. Wbrew pozorom nie chodzi o ustanowienie nowych wolności, lecz ich odzyskanie, to zatem apel do przeszłości, a nie projektowanie nowego ustroju. Lewellerzy odwoływali się przy tym do swej wizji anglosaskiej przeszłości i angielskiej tradycji parlamentarnej, w istocie więc znaleźć można w Agreement tak stare i fundamentalne elementy angielskiej tradycji konstytucyjnej, jak prawo do wnoszenia petycji, prawo do procesu przed sądem czy zakaz arbitralnego uwięzienia. Choć odtworzenie starożytnego

51 W. Haller, G. Davies, Introduction, w: W. Haller, G. Davies, The Leveller Tracts, 1647-1653, s. 10 .

52 An Agreement of the Free People of England [Mai 1, 1649], w: Don M. Wolfe, Leveller Manifestoes of the Puritan Revolution..., s. 402-403.

53 Ibidem, s. 410.

54 D.A. Orr, Constitutionalism: Ancient, Modern and Early Modern in the Agreements of the People, w: Ph. Baker, E. Vernon (ed.), The Agreements of the People, the Levellers and the Constitutional Crisis of the English Revolution, Palgrave Macmillan, Hampshire, New York 2012, s. 77. 
ustroju było poza możliwościami lewellerów i nie leżało w zamiarze ${ }^{55}$, to jak zauważył w Putney Edward Sexby ,zaangażowaliśmy się w to królestwo i zaryzykowaliśmy nasze życie jedynie dlatego, by odzyskać nasze przyrodzone uprawnienia i przywileje jako Anglików"56.

Lewellerzy zatem przyjmujący indywidualistyczną perspektywę wyciągnęli ostateczne i logiczne wnioski z koncepcji suwerenności ludu, traktując ją dosłownie. Dla nich to nie Król czy Parlament byli realnym podmiotem władzy najwyższej (co w istocie niczego nie zmieniało), lecz lud Anglii traktowany jako całość dorosłej męskiej populacji. Skoro każdy człowiek jest swą własnością, to i wspólnota składająca się z takich jednostek nie może być niczyją własnością, lecz dzierży wyłączną władzę nad samą sobą, zatem „absolutna Najwyższa Władza spoczywa w Ludzie, który składa się z poszczególnych jednostek, a zatem legalna i formalna władza przysługuje tylko jego Przedstawicielom, kolektywnemu ciału przedstawicielskiemu, które wybrane zostało przez nich i zebrane w Parlamencie" 57 . Parlament nie był więc suwerenny, lecz przysługiwała mu jedynie rola reprezentanta zbiorowego suwerena dzierżącego niepodzielnie suwerenność, był jedynie jego instrumentem niezbędnym tylko z technicznego punktu widzenia. Powstały w wyniku umowy rząd wspólnoty za jedyne zadanie ma zatem ochronę wolności i uprawnień jednostek, ograniczony jest więc przez prawo naturalne zmaterializowane w konstytucji. Ponieważ ,władza Parlamentu jest władzą powierzoną mu przez lud (który go wybrał) dla jego dobra, bezpieczeństwa i wolności, dlatego Parlament nie może sprawiedliwie uczynić niczego, co czyni lud mniej bezpiecznym i mniej wolnym, niż był wcześniej"58. Dlatego, pisze Lilburne, zadaniem ,wybranych i obdarzonych zaufaniem Powierników Ludu, od którego [...] cała władza jest wyprowadzana, jest uwolnić nas od wszelkiego poddaństwa i niewoli, ponieważ nasze wolności i swobody są prawdziwą różnicą odróżniającą ludzi od zwierząt"59. Lilburne stoi więc w opozycji wobec każdej formy tyrańskiego rządu, dostrzegał go bowiem nie

55 R.T. Vann, The Free Anglo-Saxons. A Historical Myth, Journal of the History of Ideas 1958/19, s. 271.

56 At the General Council of the Army, Putney, 29 October 1647, w: A. Sharp, The English Levellers..., s. 119-120.

57 J. Lilburne, Regall Tyrannie Discovered..., s. 38-39.

58 W. Walwyn, England's Lamentable Slaverie Proceeding from the Arbitrarie will, severitie, and Injustices of Kings, Negligence, corruption, and unfaithfulnesse of parliaments, w: W. Haller, Tracts on Liberty in the Puritan Revolution 1638-1647, vol. III, s. 313.

59 J. Lilburne, England's New Chains Discovered, Or the Serious Apprehensions of a Part of the People in Behalf of the Commonwealth; (Being Presenters, Promoters and Approvers of the Large Petition of 11 September 1648), w: A. Sharp, The English Levellers..., s. 156. 
tylko w upadłej tyranii, lecz w porządku (a raczej chaosie), który nastał po niej. „Parlament - pisał - może być bardziej nieograniczony w swej władzy i gorszy od króla, ponieważ rozum nie może sobie wyobrazić, by jeden człowiek mógł wpaść na pomysł tak absolutnej tyranii tam, gdzie duch tyranii działa w przeważającej liczbie członków tego ciała" ${ }^{60}$. Absolutne rządy parlamentu i armii budziły w nim taką samą odrazę, jak rządy króla z Bożej łaski. Dlatego, by umożliwić szybkie i łatwe usunięcie tyranów, jakimi stać się mogą reprezentanci, proponował coroczne wybory, pozwalające zastąpić ich ludźmi cnotliwymi i zatroskanymi o wolność wspólnoty i jej obywateli.

\section{V.}

Agreement jest więc w istocie pierwszym projektem konstytucji opartym na suwerenności ludu i istnieniu przyrodzonych ludzkich uprawnień i w tym znaczeniu jest rewolucyjny ${ }^{61}$. Jego wyjątkowość polega także na tym, że o ile późniejszy liberalny konstytucjonalizm szukał ograniczeń władzy przede wszystkim $\mathrm{w}$ ich podziale, lewellerzy na poziomie konstytucyjnym ograniczają władze państwa jako takiego. Nauczeni doświadczeniem monarchii i republiki lewellerzy dostrzegali zagrożenie nie w podmiocie władzy, lecz w jej zakresie, ponieważ „większość ludzi raz obdarzonych władzą wypacza ją tak samo dla własnej dominacji i ze szkodą dla naszego Pokoju i Wolności” ${ }^{2}$. By nie zamieniła się w tyranię, musi być więc władzą ograniczoną, by nie ważyła się sięgnąć do absolutystycznych praktyk. W myśli Lilburne'a i reszty lewellerów daje się zatem zauważyć konstytutywną dla ich stylu myślenia dialektykę pomiędzy jednostką i państwem, która zbliża ich do liberalnego spojrzenia na instytucje polityczne. Uprawnienia, o których pisze Lilburne, nie mają bowiem charakteru wewnętrznego czy duchowego, lecz przyjmują postać określonych wolności chroniących przed działaniami arbitralnej władzy. Są one bowiem ważniejsze niż każda zewnętrzna władza, czymś więcej niż tylko pozytywną wolnością czynienia czegoś, nie mają związku ze statusem i pozycją społeczną oraz nie wynikają z przynależności do wspólnoty czy państwa. Dlatego „człowiek rządzący przez swe pragnienia, a nie przez prawo jest stworzeniem, które nie zostało stworzone przez Boga, ani za Boga aprobatą [...] i chociaż mówi się, że tacy ludzie są

60 J. Lilburne, An Hue- and Cry after the Fundamental Laws and Liberties of England, nn, London 1653 , s. 4.

61 D. Wootton, Leveller democracy and the Puritan Revolution..., s. 412-413.

${ }^{62}$ An Agreement of the Free People of England..., s. 405. 
bogami na ziemi, to takiego człowieka nazwać można tylko diabłem, bogiem tego świata" ${ }^{63}$. Wedle Lilburne’a zatem, tyrani „przywłaszczają szczególne królewskie prerogatywy Boga samego" ${ }^{44}$, „nie uznają bowiem żadnych reguł i rządzą jedynie wedle swej woli" ${ }^{65}$. Dlatego trzeci Agreement zawiera szczegóły dotyczące rozwiązań konstytucyjnych proponowanych przez lewellerów, mających zapobiec odrodzeniu się tyrańskiej władzy. W ich zamiarze najwyższą władzę w państwie sprawować miał pochodzący z wyborów, regularnie obradujący i odnawiany, z jasno i wyraźnie zakreślonymi kompetencjami, składający się z 400 deputowanych bez prawa reelekcji. Musiał być on jednoizbowy, co logicznie wynikało z samej koncepcji umowy i odrzucenia przywilejów arystokratycznych. Istnienie izby wyższej kłóciłoby się bowiem z zasadą suwerenności ludu i zasadą równości. Samo pojęcie godności para, który zasiada w Parlamencie nie na mocy wyboru, lecz przez sam fakt szlachectwa było sprzeczne $\mathrm{z}$ całą argumentacją lewellerów.

Sam Parlament wedle autorów wybierany miał być zgodnie z zupełnie nowymi zasadami. Zamiast, jak proponowali grandowie, by reprezentacja poszczególnych okręgów była proporcjonalna do płaconych przez nie podatków, Lilburne proponował reprezentację proporcjonalną do liczby wolnych obywate$1 i^{66}$. Istotą tyrani było bowiem dla Lilburne'a również arbitralne uniemożliwienie jednostkom prawa do politycznego zaangażowania ${ }^{67}$. Choć w pierwszym Agreement jest jedynie mowa o dostosowaniu ilości reprezentantów do ilości mieszkańców, w trzecim mamy już do czynienia ze szczegółowym opisem dystrybucji mandatów proporcjonalnie do ludności okręgów wyborczych i opisem procedury wyborczej, antycypującym w dużej mierze reformę z 1832 r. pozbawiającą mandatów zgniłe miasteczka.

Równocześnie radykalne były propozycje lewellerów w kwestii praw wyborczych, lecz wynikały wprost z ich koncepcji uprawnień i umowy. Ich opinie w tej sprawie zmieniały się w całym okresie działalności stronnictwa, lecz wedle ostatniej propozycji z trzeciego Agreement mieliby je posiadać wszyscy wolni mężczyźni po ukończeniu 21 roku życia, za wyjątkiem służby i jałmużników

${ }^{63}$ J. Lilburne, An Impeachment of High Treason..., s. 1.

${ }^{64}$ J. Lilburne, Regall Tyrannie Discovered..., s. 11.

65 J. Lilburne, The Oppressed Mans Oppressions Declared: Or, an Epistle Written by Lieut. Col. John Lilburne, Prerogative-prisoner ... in the Tower of London, to Col. Francis West, Lieutenant Thereof, nn, London, s. 24.

${ }^{66}$ G.H. Sabine, A History of Political Theory, Holt, Rinehart and Winston, New York 1962, s. 487.

${ }^{67}$ J. Lilburne, Strength Out of Weaknesse..., s. 13. 
oraz rojalistów pozbawionych tego prawa na 10 lat (co interesujące, nie ma jednak mowy o wykluczeniu od praw politycznych katolików). Bez względu na szacunki doprowadziłoby to do radykalnego wzrostu uprawnionych do głosowa$n^{6}{ }^{68}$. Władza wykonawcza, której wobec supremacji Parlamentu poświęcono niewiele miejsca, zredukowana została do komitetu składającego się z osób niebędących jego członkami i działającego jedynie pomiędzy sesjami Parlamentu, ponieważ ,jest jedną z najbardziej niesprawiedliwych rzeczy na świecie, że ci, którzy tworzą prawo powinni być jego wykonawcami" ${ }^{69}$. Parlament został pozbawiony prawa wykonywania uchwalanych przez siebie ustaw oraz, co ważne, sprawowania władzy sądowniczej z wyjątkiem pociągania do odpowiedzialności funkcjonariuszy publicznych. Jest to oczywista propozycja wobec faktu, że lewellerzy byli wielokrotnie sądzeni nie przez sądy, lecz specjalne komitety parlamentarne. Ich propozycja zmierzała zatem do uwolnienia władzy sądowniczej spod aktualnej presji politycznej i uczynienia z niej bezstronnego arbitra, a nie narzędzia walki z przeciwnikami. Dlatego prawo sądzenia przekazane zostałoby w zamyśle Lilburne'a i towarzyszy sądom przysięgłym odpowiedzialnym przed Parlamentem.

Agreement odrzuca więc model ustroju mieszanego, zamiast tego w propozycjach lewellerów można doszukać się elementów podziału władz ${ }^{70}$, choć proponowane przez nich konkretne rozwiązania ustrojowe wydają się $\mathrm{w}$ tym względzie być pokłosiem ich osobistych doświadczeń, a nie głębokiego teoretycznego namysłu. $\mathrm{O}$ wiele ważniejsze jest bowiem określenie granic wszelkiej władzy. Stąd w trzecim Agreement mamy do czynienia ze szczegółowym i enumeratywnym określeniem zadań Parlamentu, którymi są: „1. ochrona pokoju i handlu z innymi narodami, 2. zachowanie naszych bezpiecznych gwarancji i bezpieczeństwa naszych istnień, wolności, własności i posiadłości zawartych w Petycji o prawa [...], 3. ściąganie podatków i wszystko to, co sprzyja tym celom lub zmierza do powiększenia naszej wolności, naprawieniu krzywd i pomyślności naszej Republiki”71. Celem Parlamentu jest więc zwiększanie

68 Dotyczące tego szacunki są różne i sięgają nawet $80 \%$ dorosłej męskiej populacji - R. Ashcraft, Revolutionary Politics and Locke's Two Treatises of Government, Princeton University Press, Princeton 1986, s. 152.

69 J. Lilburne, Englands Birth-Right Justified Against all Arbitrary Usurpation, whether Regall or Parliamentary, or under what Vizor soever, w: W. Haller, Tracts on Liberty in the Puritan Revolution 1638-1647, vol. III, s. 289.

70 M.C. Vile, Constitutionalism and the Separation of Powers, Liberty Found, Indianapolis 1998 , s. 49.

71 An Agreement of the Free People of England..., s. 405. 
obszaru wolności, stąd dla lewellerów tak istotne jest ograniczenie roli państwa, zmniejszenie podatków, likwidacja monopoli i wszelkich nadużyć zagrażających wolności. Dlatego autorzy Agreement szczegółowo w kilkunastu punktach wyliczają sprawy wyłączone spod kompetencji Parlamentu. Tworzą zatem nowoczesne w owym czasie i unikalne w konstytucyjnej tradycji angielskiej rozwiązanie prawne w akcie prawa pisanego, a nie tradycji i zwyczajach, widzące wolnościowy fundament państwa. Gdyby ich nadzieje się spełniły, byłaby to pierwsza pisana konstytucja w nowożytnej Europie. Zamiast tego jednak stał się nim Cromwellowski Instrument of Government, który był narzędziem rewolucyjnej dyktatury.

\section{Rekapitulacja}

Podczas gdy lewellerzy usiłowali dokonać nieudanej rewolucji demokratycznej, Cromwell powołał do życia oligarchiczne państwo wojskowej dyktatury, zabezpieczającej interesy szlachty i wielkich kupców, którzy stanęli po stronie Parlamentu. Zmienił się ustrój, lecz normańskie jarzmo pozostało, a „wszyscy członkowie tego narodu pozostali ciągle niewolnikami [...] żyjąc pod prawem i rządami Wilhelma"72. Protektorat, który ustanowił Cromwell był dla Lilburne'a nową tyranią, rządami „uzbrojonych złodziei i rabusiów"73. Stąd jego otwarty i nieustępliwy sprzeciw wobec nowego reżimu tak opresyjnego, że jak napisał, zwracając się do Lorda Protektora, „,wolałbym raczej żyć pod rozsądnie ograniczoną władzą Króla, niż pod tobą i twoją nową Tyranią Miecza nazywaną Republiką"74. Stanęli więc lewellerzy w opozycji do nowego reżimu w bardzo różnorodnym towarzystwie, razem z rojalistami, prezbiterianami i Szkotami, stając się celem nowej władzy. W końcu w roku 1649 Lilburne został aresztowany wraz w towarzyszami i oskarżony o zdradę za publikację drugiej części pamfletu Englands new Chains discovered uznanego przez Parlament za „skandaliczny i buntowniczy"75. Ostatecznie jednak przy aplauzie publiczności został razem z towarzyszami uniewinniony i (po pewnym czasie i niechętnie)

2 Cyt. za: Ch. Hill, The Norman Yoke, w: idem, Puritanism and Revolution. Studies in Interpretation of the English Revolution of the $17^{\text {th }}$ Century, Secker\&Warburg, London 1958, s. 82.

73 J. Lilburne, A Salva Libertate, Sent to Collonell Francis West Lieutenant of the Tower of London, on Fryday the fourteenth of September 1649, nn, London 1648, s. 1.

74 J. Lilburne, Strength Out of Weaknesse..., s. 12.

75 A Declaration of the Commons Assembly in Parliament, Against a Scandalous Book Entituled, The Second part of England's new Chains discovered, \& c., Edward Husband, London 1649, s. 1. 
uwolniony, co przebywający w Irlandii Cromwell przyjął z wiele mówiącym milczeniem. Lecz był to jedynie łabędzi śpiew lewellerów. Cromwell żelazną ręką zdusił opozycję poprzez egzekucje i uwięzienia, pozbawiając wpływów $\mathrm{w}$ armii także i ich. Oferując ograniczoną tolerancję religijną i zaspokajając roszczenia armii, pozbawił ich też naturalnego społecznego zaplecza ${ }^{76}$.

W roku 1652 Lilburne, przy okazji rozpatrywania prywatnego sporu, skazany został na dożywotnią banicję. Spędził ją w Holandii, bezustannie spiskując $\mathrm{i}$ atakując $\mathrm{w}$ swych pismach wojskową dyktaturę. Powrócił w kolejnym roku tylko po to, by znowu stanąć przed sądem, mimo że w liście do Cromwella obiecał „żyć tak cicho i pokornie wobec obecnej i przyszłej władzy jak zwykły człowiek"77. Jego popularność w armii i wśród mieszkańców Londynu była jednak tak duża, że i tym razem nie zdecydowano się na jego skazanie. Nakazano jednak jego osadzenie w Tower. $\mathrm{Z}$ czasem przeniesiono go do więzienia w Dover, pozwalając na kilkudniowe przerwy w wykonywaniu kary. W ten sposób purytanie, którzy rozpoczęli wojnę domową w imię przywrócenia starożytnej konstytucji i odwiecznych swobód Anglików, gwałcili Habeas corpus, jeden z najważniejszych jej fundamentów. Osobiste doświadczenia Lilburne'a potwierdziły jego intuicję, że rządy, parlamenty i królowie się zmieniają, lecz władza, jeśli ma ku temu możliwość, bezlitośnie zwalcza wszelkie przejawy krytyki. Ponurym memento są słowa, które padły jeszcze podczas jego uwięzienia w roku 1649 w rozmowie z Hugh Peterem, zagorzałym cromwellowcem: „Wolałbym raczej żyć w Turcji - rzekł pułkownik - pod rządami wielkiego Sułtana, niż w Anglii pod rządami twoich religijnych mistrzów z White-hall i Westminsteru, ponieważ nie ma na świecie większego tyrana lub prześladowcy, niż apostata, który odwraca się plecami do sprawiedliwości, słuszności i prawdy. Jeśli chodzi o rzeczy obecne Panie Peter, które odróżniają mnie od twoich mistrzów, to to, że jeśli byłoby to możliwe wolałbym raczej żyć siedem lat pod rządami starego króla Karola (pomimo, że został ścięty jako tyran), nawet jeśli był gorszy od obecnego Parlamentu, niż rok pod rządami obecnej władzy"78. Te słowa wypowiedziane przez oddanego sprawie żołnierza Parlamentu mówią wystarczająco dużo o nastrojach, jakie panowały w Anglii pod rządami Cromwella.

76 J.P. Sommerville, Absolutism and revolution in the seventeenth century..., s. 415.

77 J. Lilburne, The Banished man's suit for Protection To his Excellency The Lord Generall Cromwell, Being the humble address of Lieutenant Colonel John Lilburn, Thomas Newcomb, London 1653, s. 1.

78 J. Lilburne, A Discourse betwixt Lieutenant Colonel John Lilburne Close Prisoner in the Tower of London, and Mr. Hugh Peter: upon May 25 1649. Published by a friend, for the publick benefit, nn, London 1649, s. 8. 
Nie wiadomo jednak, czy Lilburne cieszyłby się, że ostatecznie okazały się prorocze, gdy 3 lata po jego śmierci, mając dość nieudanych eksperymentów i wojskowej tyranii, wybrano rojalistyczny parlament, który uznał, że Karol II jest królem od śmierci ojca. Zatem z konstytucyjnego punktu widzenia przez poprzednie dwanaście lat nie działo się nic... Pośmiertnym, i właściwie jedynym, sukcesem Free-born Johna było jednak to, że jego naturalne i przyrodzone uprawnienia weszły na stałe do liberalnego wyznania wiary za sprawą Locke'a, Jeffeersona i Paine'a.

\section{Bibliografia}

Ashcraft Richard, Revolutionary Politics and Locke's Two Treatises of Government, Princeton University Press, Princeton 1986.

Aylmer Gerald E. (ed.), The Interregnum. The Quest for Settlement, Archon Books, Hamden 1972.

Baker Philip, Vernon Elliot (ed.), The Agreements of the People, the Levellers and the Constitutional Crisis of the English Revolution, Palgrave Macmillan, Hampshire, New York 2012.

Braddick Michael J., Smith David L., The Experience of Revolution in Stuart Britain and Ireland, Cambridge University Press, Cambridge, New York, Melbourne, Cape Town, Singapore, Sao Paulo, Delhi, Tokyo, Mexico City 2011.

Brailsford Henry N., The Levellers and the English Revolution, Spokesman, Nottingham 1976.

Brown Luis F., The Political Activities of the Baptists and Fifth Monarchy Men in England During the Interregnum, Oxford University Press, London 1912.

Burges Glenn, The Politics of the Ancient Constitution. An Introduction to English Political Thought, 1603-1642, Palgrave Macmillan, Basingstoke, London 1992.

Henderson Burns J., Goldie Mark (ed.), The Cambridge History of Political Thought, 1450-1700, Cambridge University Press, Cambridge 1991.

Foxley Rachel, John Lilburne and the Citizenship of "Free-born Englishmen", The Historical Journal 2004/47/4, s. 849-874.

Foxley Rachel, The Levellers. Radical Political Thought in the English Revolution, Manchester University Press, Manchester, New York 2013.

Gentles Ian, Morrill John, Worden Blair (ed.), Soldiers, writers and statesmen of the English Revolution, Cambridge University Press, Cambridge 1998.

Glover Samuel D., The Putney Debates: Popular versus Élitist Republicanism, Past \& Present, Aug., 1999/164, s. 47-80.

Godwin William, History of The Commonwealth of England. From its Commencement, to The Restoration of Charles The Second, Henry Colburn, London 1826.

Gregg Pauline, Free-Born John. The Biography of John Lilburne, Phoenix Press, London 2000.

Haller William (ed.), Tracts on Liberty in the Puritan Revolution 1638-1647, Columbia University Press, New York 1934.

Haller William, Davies Godfrey (ed.), The Leveller Tracts, 1647-1653, Peter Smith, Gloucester 1964. 
Hill Christopher, Puritanism and Revolution. Studies in Interpretation of the English Revolution of the $17^{\text {th }}$ Century, Secker\&Warburg, London 1958.

Hill Christopher, The World Turned Upside Down. Radical Ideas During the English Revolution, Penguin Books, London 1991.

Kewes Paulina (ed.), The Uses of History in Early Modern England, University of California Press, San Marino 2006.

Lecler Joseph, Historia tolerancji w wieku reformacji, przekł. Lesława Kühn, Halina Kühn, Pax, Warszawa 1964.

Lilburne John, A Declaration to the Free-Born People of England, Concerning the Government of the Commonwealth, George Horton, London 1654.

Lilburne John, A Discourse betwixt Lieutenant Colonel John Lilburne Close Prisoner in the Tower of London, and Mr. Hugh Peter: upon May 25 1649. Published by a friend, for the publick benefit, nn, London 1649.

Lilburne John, A Salva Libertate, Sent to Collonell Francis West Lieutenant of the Tower of London, on Fryday the fourteenth of September 1649, nn, London 1648.

Lilburne John, An Answer to Nine Arguments. Written by T.B., nn, London 1645.

Lilburne John, An Hue- and Cry after the Fundamental Laws and Liberties of England, nn, London 1653.

Lilburne John, An Impeachment of High Treason against Oliver Cromwel, nn, London 1649.

Lilburne John, Englands Weeping Spectacle: Or, The Sad Condition of Lieutenant Colonell John Lilburne, nn, London 1648.

Lilburne John, Liberty Vindicated against Slavery, Shewing, that Imprisonment for Debt, Refusing to Answer Interrogatories, Long Imprisonment, Though for Just Causes, nn, London 1646.

Lilburne John, London's Liberty in Chains discovered, A Postscript written by Lieutenant Colonell Iohn Lilburn, Prisoner in the Tower of London, nn, London 1646.

Lilburne John, Regall Tyrannie Discovered, Or, A Discourse Shewing that All Lawfull ... Instituted Power by God Amongst Men, is by Common Agreement and Mutual Consent ..., nn, London 1647.

Lilburne John, Strength Out of Weaknesse: or, the Final Plea of J. Lilburne, nn, London 1649.

Lilburne John, The Grand Plea of Lieut. Col. John Lilburne: prerogative prisoner in the Tower of London, nn, London 1647.

Lilburne John, The Oppressed Mans Oppressions Declared: Or, an Epistle Written by Lieut. Col. John Lilburne, Prerogative-prisoner ... in the Tower of London, to Col. Francis West, Lieutenant Thereof, nn, London.

Lilburne John, The Prisoners Plea for a Habeas Corpus: Or an Epistle Writ by L.C. Joh. Lilburne Prerogative Prisoner in the Tower of London the 4. of Aprill, to the Honourable Mr. W. Lenthall Speaker of the House of Commons, nn, London 1648.

Lilburne John, The Upright Mans Vindication or An Epistele writ by John Lilburne Gent. Prisonet in Newgate, August 1653, nn, London 1653.

Lilburne John, The Banished man's suit for Protection To his Excellency The Lord Generall Cromwell, Being the humble address of Lieutenant Colonel John Lilburn, Thomas Newcomb, London 1653.

Macpherson Crawford B., The Political Theory of Possessive Individualism, Clarendon Press, Oxford 1990. 
Manning Brian, The English People and the English Revolution, Peregrine Books, Harmondsworth 1978.

Morton Arthur L., World of the Ranters. Religious Radicalism in the English Revolution, Lawrence \& Wishart, London 1970.

Pease Theodore C., The Leveller Movement. A Study in the History and Political Theory of the English Great Civil War, Oxford University Press, Washington, London 1916.

Pocock John G.A., The Ancient Constitution and the Feudal Law. A Study of English Historical Thought in the Seventeenth Century. A Reissue with a Retrospect, Cambridge University Press, Cambridge, London, New York, New Rochelle, Melbourne, Sidney 1987.

Sabine George H., A History of Political Theory, Holt, Rinehart and Winston, New York 1962.

Schenk Wilhelm, A Seventeenth-Century Radical, The Economic History Review 1944/14/1, s. 74-83.

Scherger George L., The Evolution of Modern Liberty, Longmans, Green, and Co., London, Bombay 1904.

Sharp Andrew (ed.), The English Levellers, Cambridge University Press, Cambridge, New York, Melbourne 1998.

Sharp Andrew, John Lilburne's Discourse of Law, Political Science 1988/40, s. 18-33.

Skinner Quentin, History and ideology in the Puritan Revolution, Historical Journal 1965/ VIII/2, s. 151-178.

Skinner Quentin, Visions of Politics, vol. III: Hobbes and Civil Science, Cambridge University Press, Cambridge, New York, Melbourne, Madrid, Cape Town 2002.

Underwood Alfred C., A History of the English Baptists, Kingsgate Press, London 1947.

Vann Richard T., The Free Anglo-Saxons. A Historical Myth, Journal of the History of Ideas 1958/19, s. 259-272.

Vile Maurice C., Constitutionalism and the Separation of Powers, Liberty Found, Indianapolis 1998.

Wolfe Don M. (ed.), Leveller Manifestoes of Puritan Revolution, Thomas Nelson and Sons, New York, London, Edinburgh, Toronto, Melbourne 1944.

Wootton David, Leveller democracy and the Puritan Revolution, w: James Henderson B., Mark Goldie (ed.), The Cambridge History of Political Thought 1450-1700, Cambridge University Press 1994, s. 412-433.

Wormuth Francis D., The Origins of Modern Constitutionalism, Harper, New York 1949.

Zagorin Perez, A History of Political Thought in the English Revolution, Routledge \& Kegan Paul, London 1965. 
Tomasz TULEJSKI

\section{JOHN LILBURNE - THE MAN, WHO BELIEVED TOO MUCH IN THE FREEDOM}

\section{( Sum mary)}

The Levellers was a political movement during the English Civil War, that advocated the radical political reforms because in those Agreements of the People arguably the first time contemporary democratic ideas had been formally framed and adopted by a political movement. One of Levellers' leaders and influenced political agitator was John Lilburne, the officer of the New Model Army, also known as Freeborn John. In this Article the Author tries to reconstruct Lilburne's coherent political doctrine from his speeches, letters and political manifestoes. He argues that Freeborn John's thought is rooted in Baptist theology because his political and social argument is secularisation of Bapists' concepts of the origin the Church. From that fact, that congregational government called for and expressed the equality and responsibility of believers under the Lordship of Christ, and that in Jesus Christ all people are equal and everyone is free to be in relationship with God and to express his faith voluntarily, Lilburne infers universal and natural rights, the conventional origin of the society, extended suffrage, general equality before the law, and religious tolerance.

Keywords: Lilburne; Levellers; English Civil War 